Man and Nature

L'homme et la nature

\title{
David Hume and the Empiricist Theory of Law
}

\section{Sheldon Wein}

Volume 9, 1990

URI : https://id.erudit.org/iderudit/1012608ar

DOI : https://doi.org/10.7202/1012608ar

Aller au sommaire du numéro

Éditeur(s)

Canadian Society for Eighteenth-Century Studies / Société canadienne d'étude du dix-huitième siècle

ISSN

0824-3298 (imprimé)

1927-8810 (numérique)

Découvrir la revue

Citer cet article

Wein, S. (1990). David Hume and the Empiricist Theory of Law. Man and Nature / L'homme et la nature, 9, 33-44. https://doi.org/10.7202/1012608ar

Copyright (c) Canadian Society for Eighteenth-Century Studies / Sociéte canadienne d'étude du dix-huitième siècle, 1990
Ce document est protégé par la loi sur le droit d'auteur. L'utilisation des services d'Érudit (y compris la reproduction) est assujettie à sa politique d'utilisation que vous pouvez consulter en ligne.

https://apropos.erudit.org/fr/usagers/politique-dutilisation/ 


\section{David Hume and the Empiricist Theory of Law}

\section{INTRODUCTION}

John Stuart Mill thought that David Hume's contribution to the development of an empiricist theory of law and justice was entirely negative; Hume prepared the groundwork for others but did not actually start on the construction of an empiricist jurisprudence. ${ }^{1}$ Few doubt that Hume did a great deal to pave the way for those empiricists who followed. But the received view is that Hume was more than the brilliant negative thinker Mill suggested he was; most hold that Hume also contributed to the development of an empiricist account of both law and justice. This paper offers an interpretation of Hume which accords with Mill's assessment of Hume's contribution.

A general theory of law tells us what law is, what it ought to be, and what sort of relationship exists between law and morality. Since laws do not occur in isolation but in legal systems and since justice is the primary moral property we want in a legal system, we can say that a complete philosophy of law tells us what a legal system really is, what principles ought to be used to specify the content of a just legal system, and, finally, what relationship there is between legality and justice.

Prior to Hume, the dominant philosophy of law was natural law theory. While natural law theory comes in many guises, they all hold that reason, when turned to the task of reflection on the natural order of things, can tell us what social arrangements are just. Second, they hold that there is some kind of conceptual connection between law and morality so that what is legal and what is just are not logically distinct. ${ }^{2}$ Finally, natural law theorists hold that, because the law is by its very nature infused with morality and because rationality allows us to discover our proper ends, there is a single proper legal outcome to every possible legal case.

Following Hume, natural law theories fell out of favor. And now an alternative philosophy of law, which we may call legal empiricism, so dominates jurisprudence that, in the English speaking world at any rate, it has come to be what one observer has called 'the ruling theory. ${ }^{\prime 3}$ This 
paper examines the extent to which Hume is responsible for the demise of natural law theories and for the rise of various versions of legal empiricism. I will argue that while his destructive influence was great, his constructive influence was pretty much confined to laying the groundwork for legal empiricism. Hume did not even try to construct a viable empiricist theory either of what law is, or of what it ought to be.

\section{THE DEMISE OF NATURAL LAW}

The standard interpretation of Hume agrees with Mill that Hume was the greatest of enemies to natural law theorists. Hume's attack on natural law theories consists primarily of an attack on the role they give to reason in both morality and legal thinking. Hume holds that morality is not based on reason but on the sentiments. Thus, Hume says that

The hypothesis which we embrace is plain. It maintains that morality is determined by sentiment. It defines virtue to be whatever action or quality gives to a spectator the pleasing sentiment of approbation; and vice the contrary. We then proceed to examine a plain matter for fact, to whit, what actions have this influence. We consider all the circumstances in which these actions agree, and thence endeavor to extract some general observations with regard to these sentiments. ${ }^{4}$

While it is much disputed exactly what Hume meant by this and by other claims that morality is based on sentiment rather than on reason, ${ }^{5}$ one thing is clear: his arguments against the notion that reason alone is the guide to moral knowledge were influential in turning subsequent thinkers away from the natural law path in normative jurisprudence. ${ }^{6}$ Furthermore, when Hume discusses legal reasoning, he denies that reason is capable of providing one best outcome to every legal case. ${ }^{7}$ Of course, Hume was by no means completely successful in ridding the world of natural law theories, but his role in undermining their popularity was undeniably a vital one. ${ }^{8}$

\section{LEGAL EMPIRICISM}

Before we can decide whether Hume was a legal empiricist, or whether he was even on the way to becoming one, we need to examine the general tenets of that philosophy of law. Legal empiricism is a general theory about law and morality, a central tenet of which is the separation thesis, the doctrine that what is law and what ought to be law are logically 
distinct questions. ${ }^{9}$ No one can consistently be a legal empiricist and hold that the law is necessarily infected by morality. ${ }^{10}$ Thus, legal empiricism has both a conceptual part - a part that tells us what law is and a normative part - a part that tells us what laws we ought to have. The conceptual part of legal empiricism is legal positivism. While there are many versions of legal positivism, all accept the sources thesis, the thesis that whether something is a law is determined by its source(s). Thus, laws are a species of rules differentiated from other rules by their history. What features of the history of a rule makes it a law is something that has been vigorously disputed among legal positivists. However, these disputes need not detain us for we may say that, according to all legal positivists, a law is a rule with whatever is the law-making pedigree. ${ }^{11}$

We need at this point to note a consequence of legal positivism's acceptance of the sources thesis. If what is law is determined by what rules have the law-making pedigree, then inevitably there will be cases where, whether because the rules are unclear or because there are no relevant rules, the judge must make new law to decide the outcome of the case. In such cases the judge's decision is not guided by the law, for in such a case there is no law to guide her. Rather, she must simply choose, on no firm legal basis, what is to become the law. This thesis, the no-right-answer thesis, is a central thesis of empiricist jurisprudence.

Given the separation thesis, the legal empiricist can offer almost any theory about what ought to be law, except, of course, a natural law account of what ought to be law. Furthermore, since legal positivism simply gives an account of what law is (and is completely silent about what law ought to be), the legal empiricist must offer some account of what makes law morally good or bad. Just as a matter of historical fact, most legal empiricists have been utilitarians of one sort or another, which is hardly surprising given that utilitarianism seems like the moral theory a philosopher with an empiricist bent is most likely to find congenial. But, for purposes of deciding whether, and to what extent, Hume contributed to the development of legal empiricism, it would be artificial to require that he contributed to the development of utilitarianism. All that is required is that he contributed to any theory of justice compatible with legal positivism.

In summary, we may say that anyone who advances a prescriptive theory of justice which is not a natural law theory, accepts the sources thesis, and adopts the separation thesis and the no-right-answer thesis is a legal empiricist. My contention is that Hume does not come very close to meeting these conditions. 


\section{HUME AS LEGAL EMPIRICIST}

There are two ways in which one might understand the claim that Hume was a precursor to legal empiricism. In the first interpretation one might hold that certain ideas developed by Hume were important in the subsequent development of legal empiricism. Thus, one might argue (quite plausibly, I think) that the clarity with which Hume was able to distinguish between claims concerning what is the case and what ought to be the case helped create the intellectual climate necessary for the development of legal empiricism. Or one might make weaker (and hence more plausible) claim that the clarity with which Hume was able to state the virtues of a strictly empiricist philosophy was vital to the development of legal empiricism. After all, legal empiricism is the philosophy of law a good empiricist would come up with if she turned her attention to the nature and structure of legal systems. But, one might say, being a clear-headed empiricist in jurisprudence requires already having a grasp of the fundamental tenets of empiricism. And, of course, Hume's writings still remain one of the better places to go if one wants to get an understanding of the power of empiricist philosophy.

But it is not this sense of 'being a precursor to legal empiricism' which interests me here. Rather, I am interested in whether Hume himself was on the way to becoming a legal empiricist. Like Mill, I think he was not. But it is easy to see why one might think of Hume as a (budding) legal empiricist. After all, he is often interpreted as having advanced a prescriptive theory of justice, ${ }^{12}$ namely, utilitarianism; he thinks that reason is unable to discern a unique outcome for every legal case, and he is famous for having claimed that there is a fact/value gap. ${ }^{13}$ If Hume advanced a prescriptive theory of justice, then he meets the first condition for being a legal empiricist. His holding that reason cannot be the sole guide for the judge suggests that he accepts the sources thesis, the second condition for being a legal empiricist. And, his stress on the logical difference between facts and values suggests that he accepted the separation thesis, the final condition for being a legal empiricist. But, I contend that Hume's adherence to these positions is more apparent than real.

In particular, I hold that Hume had no theory of justice (utilitarian or otherwise), that he rejects the sources thesis, and, that, whatever his position on the relationship between facts and values he did not hold anything remotely like the separation thesis. While Hume certainly wrote things which appear to support the no-right-answer thesis, I doubt that he really cared about either that thesis or its implications for jurisprudence. 
HUME AS UTILITARIAN OR HUME AS A CONTRACTARIAN.

John Plamenatz, in The English Utilitarians, says that 'David Hume is rightly regarded as the founder of utilitarianism.' And he goes on to quote Leslie Steven saying of Hume that 'the essential doctrines of Utilitarianism are stated (by Hume) with a clearness and consistency not to be found in any other writer of the century' and that 'from Hume to J.S. Mill, the doctrine received no substantial alteration. ${ }^{14}$ Even if one grants that Hume was a utilitarian, to say that utilitarianism made no progress from Hume to Mill would be enough to cause Jeremy Bentham to role over in his grave, were he in one. One wonders if Steven would discuss the development of Christianity without mentioning Jesus of Nazareth!

But the view that Hume was a utilitarian is not universally shared. Jonathan Harrison, in his book Hume's Theory of Justice, says 'Hume, incidentally, was not a full-blown utilitarian' ${ }^{15}$ And in 'David Hume: Contractarian', David Gauthier argues that Hume was really a contractarian. $^{16}$

It is not surprising that utilitarians and contractarians alike would want to claim a philosopher of Hume's stature to their camp. But what is it about Hume's works which apparently lend themselves to these conflicting interpretations? (The fact that Hume never gives himself either of these labels is, of course, a contributing factor. ${ }^{17}$ But this is not surprising, for neither term was in common use when Hume was writing. $)^{18}$ Part of the reason for the disagreement is that contractarianism and utilitarianism are, in many respects, very similar theories. Each holds that what justifies both civil society and the particular social rules a society adopts is that the rules (or as Hume prefers 'conventions') further the interests of those governed by those rules. ${ }^{19}$ Or, to put it in other terms, adopting and adhering to rules which constrain the conduct of each person in various ways is justified when such rules serve to increase utility. Thus, Hume's frequent remarks that justice exists because of its usefulness or utility, that it is this feature of justice which distinguishes it from superstition, and so forth - these remarks are all compatible with both utilitarianism and with contractarianism. ${ }^{20}$ Both the contractarian and the utilitarian think that social rules are justified if, and only if, they are productive of utility. Hume constantly says we have this or that social rule (usually some rule about property) because it increases utility. So, it is hardly a surprise that Hume often sounds like a utilitarian or a contractarian. ${ }^{21}$

Furthermore, it is on the very point on which contractarians and utilitarians divide that Hume is silent. The utilitarian holds that a set of 
social rules is morally justified if, and only if, it is the set of social rules which would, in the circumstances, best serve to maximize the utility of the members of the community taken collectively. ${ }^{22}$ The contractarian, by contrast, holds that social rules are justified if, and only if, they serve to increase the utility of each member of the community taken severally. For the contractarian, but not for the utilitarian, each individual must be made better off by a set of social rules if they really are just rules. ${ }^{23}$

Which was Hume, utilitarian or contractarian? Did he think society should adopt social rules which would maximize utility taken collectively or taken severally? It seems to me that it is the beginning (but only the beginning) of insight into Hume's views on these matters to realize that he simply never noticed this difference. The fundamental difference between utilitarianism and contractarianism was something that just never struck Hume. Well, why didn't it? ${ }^{24}$ I suggest that the reason Hume's remarks on justice provide us with no grounds for choosing between the hypothesis that he was a utilitarian and the hypothesis that he was a contractarian is that he simply had no interest in the matters both theories address. He had no interest in either theory, for both contractarianism and utilitarianism are theories about what social rules we ought to adopt, but Hume was simply interested in why we have the social rules we in fact have adopted. All the great contractarians, from Hobbes and Rousseau through to David Gauthier and John Rawls, have been working to develop a theory which tells us what system of social organization we ought to adopt. ${ }^{25}$ And all the great utilitarians, from Bentham through to Harsanyi and J.J.C. Smart, have also been working to tell us how we ought to order our social arrangements. But, while contractarians and utilitarians alike are in the business of prescribing, Hume was only interested in describing. Hume never tells us what we ought to do to have a just society. Rather, he confines himself to telling us things about what our sense of justice consists in, where it comes from, and what role it plays in our moral thinking. He tells us what our conception of justice is; he does not tell us what our conception of justice ought to be. To put it in terms Hume would not like, what Hume did when he turned his mind to questions of morals was descriptive metaphys$i c s$, whereas what the utilitarians and contractarians (typically) are doing is revisionary metaphysics. ${ }^{26}$

Consider this (fairly typical) passage, 'the rules of equity or justice depend entirely on the particular state and condition in which men are placed, and owe their origin and existence to that utility, which results to the public from their strict and regular observance. ${ }^{27}$ Hume does not say that what justifies the rules of justice is utility. He says that utility is what accounts for their 'origin and existence'. Hume's remarks on justice, his insightful observations and careful analysis, amount to a description 
of what we call justice, not a prescription for social arrangements he would like to see instituted.

Of course, the rules of justice Hume described resemble the rules utilitarians and contractarians prescribe and the cause Hume cites for our having the rules we have, namely, public utility, is the very thing that contractarians and utilitarians cite as justification for social rules. But, just as description is not prescription, so a cause is not a justification. If I am correct in this, then to ask whether Hume was a contractarian or a utilitarian is to commit a category mistake. Hume did not have a theory of justice in the way that Plato or Bentham did. Hume had no theory of justice. What he did offer us was a (typically astute and insightful) description of what that which we call 'justice' is and how we came to have it. Put in terms popular with contemporary philosophers, my thesis is that Hume confined himself to doing metaethics and did not venture into the field of normative jurisprudence.

It is difficult to defend the claim that Hume neither had a prescriptive theory of justice nor was interested in formulating such a theory. I grant that Hume occasionally makes remarks which suggest he was considering advancing a theory of justice. ${ }^{28}$ However, it should be noted that $A n$ Enquiry Concerning the Principles of Morals lends no support whatsoever to the position that Hume engaged in normative theorizing. Throughout his later work, which Hume himself claimed represented his real views, he confines himself entirely to descriptive analysis of moral concepts. I submit that we should take Hume at his word and refuse to try to squeeze out of his writings an interpretation which he implicitly rejects. $^{29}$

\section{LEGAL POSITIVISM}

Even if Hume should not be thought of as contributing to the development of the normative part of legal empiricism, one might hold that he contributed to its conceptual part, legal positivism. In favor of the claim that Hume either was a legal positivist or on his way to becoming a legal positivist is the fact that he seems to think of laws as nothing but rules. And he explicitly accepts a key consequence of the legal positivist notion that laws are nothing but rules, the view that the law is not rich enough to provide a best outcome for all possible legal cases and that, hence, in some cases judges simply make law. ${ }^{30}$ But the observations the legal positivists like to hear are mixed in with a few which they would rather not hear. Thus, he observes that 'Public utility is the general object of.all courts'. ${ }^{31}$ And he constantly describes laws using moral terminology. ${ }^{32}$ I take it that no one committed to the sources thesis would make such 
remarks, for a crucial dispute between legal positivists and their opponents is a dispute over whether a complete account of the nature of law can be value neutral. And, of course, Hume should side with the legal positivist claim that there is a sharp distinction between claims about what law is and claims about what law ought to be. But Hume always describes the sources of law in moral terms, in terms of how, whatever the law is, it necessarily promotes utility. Such descriptions are completely antithetical to legal positivism and suggest that Hume was no legal positivist. Hume celebrated the ideology adopted by legal positivists as a starting point for their accounts of law, but he did not share their account of what law is.

\section{THE SEPARATION OF LAW AND MORALITY}

I have argued that Hume failed to advance a prescriptive moral theory as is required of a legal empiricist, and that he did not accept the sources thesis; all that remains is to ask if, and to what extent, he accepted the separation thesis. It is here that I think the strongest case is to be made for claiming that Hume contributed to the growth of legal empiricism. In a properly famous passage Hume says:

I cannot forbear adding to these reasonings an observation, which may, perhaps, be found of some importance. In every system of morality, which I have hitherto met with, I have always remark' $\mathrm{d}$, that the author proceeds for some time in the ordinary way of reasoning, and establishes the being of a God, or makes observations concerning human affairs; when of a sudden I am surpriz' $\mathrm{d}$ to find, that instead of the usual copulations of propositions, is, and is not, I meet with no proposition that is not connected with an ought, or an ought not. This change is imperceptible; but is, however, of the last consequence. For as this ought or ought not expresses some new relation or affirmation, 'tis necessary that it shou'd be observ'd and explain'd; and at the same time that a reason should be given, for what seems altogether inconceivable, how this new relation can be a deduction from others, which are entirely different from it. ${ }^{33}$

Here Hume vividly states what has come to be called the fact/value dichotomy. This dichotomy is essential to the separation thesis, which makes no sense if facts and values are not logically distinct. Surely, the author of this passage must be counted among those who accepted the separation thesis, or so the standard wisdom would have it.

But before granting this conclusion let me make the following observations. First, the initial claim in the passage - that is, 'I cannot forbear adding...' - is false. Hume could forbear adding this point, and when 
he came to present his considered philosophy in the Enquiries, neither this passage, nor anything like it, is found. If it was such an important point to him, why did he leave it out of his definitive statement of his position? Second, one can interpret the passage as an injunction against using 'ought' language in the prescriptive way I have been claiming Hume never really uses it. Finally, the passage is not about law and morality, but about the basis on which one might construct a morality. So Hume likely was not even thinking of the subject matter dealt with by the separation thesis when he wrote this passage.

I conclude that to claim Hume was a legal empiricist on the basis of one passage - a passage which stands isolated in a work he subsequently disowned - is stretching things too far. This is not to deny that the insight expressed in the is/ought passage had no role in the subsequent development of the separation thesis. In that respect it was vital. But we must distinguish between Hume's influence and his own position. The evidence simply does not support the claim that Hume himself held the separation thesis.

\section{CONCLUSION}

I do not deny that Hume made a great contribution to the history of ideas. His powerful works radically altered the way philosophers looked at society. One result of their looking at society in new (and largely Humean) ways was the development of legal empiricism. But to say that Hume created the conditions which allowed for the development of legal empiricism is not to say that he was himself a legal empiricist. On the issue of whether Hume was a legal empiricist, we must, I think, accept Mill's negative evaluation. ${ }^{34}$

\section{SHELDON WEIN}

Saint Mary's University, Halifax

\section{Notes}

1 See Mill's 'Essay on Bentham,' (first published in the London and Westminster Review, August 1838).

2 The two strongest statements of the sort of conceptual connection between law and morality are those of Augustine - 'A bad law is no law at all' - and Hobbes 
- 'No Law can be Unjust'. Most natural law theorists hold that the conceptual connection between law and morality is weaker than this.

3 Ronald Dworkin, Taking Rights Seriously (London, 1989), p.vii.

4 David Hume, Enquiries Concerning Human Understanding and Concerning the Principles of Morals, Selby-Bigge edition, p.289. All references to this work are cited as Enquiry.

5 Marie A. Martin's 'Sentiment and Judgment in Hume's Moral Theory: An Objectivist Account' (unpublished ms.) is the best discussion I know of on this aspect of Hume's work. She argues, quite convincingly, that various subjectivist interpretations of Hume are untenable.

6 Reading Hume's A Treatise of Human Nature had much the same impact on Bentham as it had on Kant, though Bentham felt as if scales had fallen from his eyes while Kant merely awoke from his dogmatic slumbers. All references to this work are to the Selby-Bigge edition and are cited as Treatise.

7 See Enquiry, p.308; Treatise, the note on pp.506-508, and Jonathan Harrison's glosses in Hume's Theory of Justice (Oxford, 1958).

8 William Blackstone (1723-1780) worked away oblivious to Hume's attack.

9 Or as John Austin put it, "The existence of law is one thing; its merit or demerit is another.' (The Province of Jurisprudence Determined, Lecture V, appended Note). Sometimes the separation thesis is taken as a consequence of the legal positivist position that what determines what the law is is its source. For present purposes it matters not whether the separation thesis depends on the sources thesis or vice versa.

10 Of course, every legal positivist is allowed to hold, what surely no one would deny, that there are many causal relations (operating in both directions) between law and morality.

11 Think of what makes a rule a rule of baseball rather than a law. Presumably it is some fact about the rule's history, such as it was made by the commissioner of baseball.

12 By a prescriptive theory of justice I mean a theory which tells us what social arrangements we ought to adopt to develop a just society. My claim is that Hume had a descriptive theory of justice in the sense that he provided us with a description of our conception of justice. On the different (meta-ethical) question of whether Hume was a prescriptivist or a descriptivist, this paper has nothing to say.

13 Treatise, Book 3, Part 1, Section 1, p.469.

14 John Plamenatz, The English Utilitarians (Oxford, 1958), p.22.

15 Jonathan Harrison, Hume's Theory of Justice (Oxford, 1981), p.87.

16 David Gauthier, 'David Hume, Contractarian,' The Philosophical Review, LXXXVIII, \#1, January 1979.

17 Even if he had, this would not be decisive. Philosophers are often mistaken about how to best characterize their own positions.

$18 \mathrm{~J}$. S. Mill claims to have invented the term utilitarianism. Certainly he is the one who made it popular. And the term contractarianism, which derives from Rousseau's Du Contract Social, seems to have acquired its present meaning only in 
this century. We should remember that Hobbes (who advanced the brand of contractarianism Gauthier thinks Hume held) generally used 'compact' rather than 'contract.'

19 I will confine my discussion to rule utilitarianism, ignoring the complications raised by act (and motive) utilitarianism.

20 For example, Hume says that 'the rules of equity or justice depend entirely on the particular state and condition in which men are placed, and owe their origin and existence to that utility, which results to the public from their strict and regular observance.' Enquiry, p.188.

21 Though, as Sidgwick observes when speaking of Hume, 'And no doubt there is a great difference between the assertion that virtue is always productive of happiness, and the assertion that the right action is under all circumstances that which will produce the greatest possible happiness on the whole': Henry Sidgwick, The Methods of Ethics (Indianapolis, 1907), pp.424-5.

22 Here I ignore the differences between total and average utilitarianism.

23 It is for this reason, that each and every person must be made better off by the rules if they are to be justified, that the contract is such an appealing device to the contractarian. No rational individual enters into a contract unless she thinks it will make her better off than she would be without the contract. Since this applies to each and every individual, the contract device produces only rules which serve to promote the interests of each taken severally.

24 Hume was aware of Plato's statement and rejection on contractarianism in the Republic and of Cicero's brief statement (see the footnote on p.189 of Enquiry), and of Hobbes's fuller statement of the theory.

25 Note that Gauthier and Rawls are much more interested in prescribing than Hobbes and Rousseau were. Indeed, moral philosophers after Hume tend to prescribe more than those before Hume. Part of my contention is that Hume failed to learn the lessons he so successfully taught subsequent philosophers.

26 The distinction between descriptive and revisionary metaphysics is drawn by P. F. Strawson in the introduction to Individuals (London, 1959). I said that utilitarians and contractarians typically do revisionary rather than descriptive metaphysics because they sometimes do descriptive metaphysics. Thus, Sidgwick's attempts in The Methods of Ethics to show that the tenets of Christian morality can be given a utilitarian basis might be construed as a descriptive rather than a revisionary project.

27 Enquiry, p.188 (italics added).

28 For an excellent defense of the claim that Hume never 'managed to say a word' about justice, see Nathan Brett, 'Hume: Justice as Property', Man and Nature, Volume VI, 1987.

29 I grant that those who would make Hume out to be advancing a normative theory can find some support in the Treatise. Hume's disavowal of this work suggests that even if, at one time, he had some inclination to advance a theory of justice, he eventually rejected that option.

30 Thus, he says, 'that jurisprudence is ... different from all the sciences; and that in many of its nicer questions, there cannot properly be said to be truth or falsehood on either side' (Enquiry, p.308), and 'where several rules, nearly equal and 
indifferent, present themselves, it is a very slight turn of thought which fixes the decision in favour of either party' (Enquiry, p.309 [see Hume's footnote]).

31 Enquiry, p.309.

32 Thus, he says that 'In every criminal trial the first object of the prisoner is to disprove the facts alleged, and deny the actions imputed to him; the second to prove, that even if these actions were real, they might be justified as innocent and lawful' (Enquiry, p.171). And this is in the context of a discussion of what role reason plays in moral judgments!

33 Treatise, Book 3, Part 1, Section 1, p.469.

34 I thank Nathan Brett, Clarence Johnson, and Thea E. Smith for helpful comments and the Saint Mary's University Senate Research Committee for a grant funding my research. 